This item was submitted to Loughborough's Research Repository by the author.

Items in Figshare are protected by copyright, with all rights reserved, unless otherwise indicated.

\title{
Seeing like a business: rethinking the role of business in regional development, planning and governance
}

PLEASE CITE THE PUBLISHED VERSION

https://doi.org/10.1080/21622671.2020.1743201

\section{PUBLISHER}

Taylor \& Francis (Routledge)

\section{VERSION}

AM (Accepted Manuscript)

\section{PUBLISHER STATEMENT}

This is an Accepted Manuscript of an article published by Taylor \& Francis in Territory, Politics, Governance on 8 April 2020, available online: http://www.tandfonline.com/10.1080/21622671.2020.1743201.

\section{LICENCE}

CC BY-NC-ND 4.0

\section{REPOSITORY RECORD}

Harrison, John. 2020. "Seeing Like a Business: Rethinking the Role of Business in Regional Development, Planning and Governance”. Loughborough University. https://hdl.handle.net/2134/11920638.v1. 


\title{
SEEING LIKE A BUSINESS: RETHINKING THE ROLE OF BUSINESS IN REGIONAL DEVELOPMENT, PLANNING AND GOVERNANCE
}

\author{
John Harrison \\ Geography and Environment \\ Loughborough University \\ Loughborough \\ Leicestershire \\ United Kingdom \\ LE11 3TU
}

j.harrison4@lboro.ac.uk

Harrison J (2020) Seeing like a business: rethinking the role of business in regional development, planning and governance. Territory, Politics, Governance 
Abstract Rather than accept the mainstream view that we need to bring the state back in to regional thinking, this paper argues that the state - and our analysis of it - is restricting understandings of urban and regional change and leading to a state-territorial trap. Analysing over forty years of literature on growth-oriented regionalism, the paper reveals important blind spots in our approaches to researching regions (and other forms of place making) and the role of business in regional development, planning and governance. Presenting a comparison of two spatial governance projects in the UK - The Peel Group's Atlantic Gateway Strategy and UK Government's Local Enterprise Partnerships - the paper reveals how business orchestrated regionalism is a new empirical reality, but one we are ill-equipped to understand. It argues that we need to move beyond the conceptual and methodological lockin of business-as-usual approaches, to start 'seeing like a business' and revealing the practical politics and pragmatism by which actors - both state and business - are engaging to effect regional change and shape regional futures.

Key words Business regionalism, state territoriality, infrastructure regions, growth politics, alternative regionalisms, Atlantic Gateway. 


\title{
SEEING LIKE A BUSINESS: RETHINKING THE ROLE OF BUSINESS IN REGIONAL DEVELOPMENT, PLANNING AND GOVERNANCE
}

\author{
"Whilst state-centred analyses provide insights into the changing terrain which \\ provides enhanced possibilities for private sector engagement, they have proved \\ largely unable to explore why businesses actually choose to engage (or not) in urban \\ governance, the mechanisms by which actors are engaged, and how the nature of \\ engagement is played out to impact upon the evolution of practice." (Syrett and
} Berotti, 2012: 2313)

\section{INTRODUCTION: FROM BRINGING THE STATE BACK IN TO SEEING BEYOND THE STATE?}

In contrast to earlier accounts arguing that globalization went together with the withering away of the state, the past two decades have witnessed a critical body of work articulating transformations in the role, function and spatiality of the state. Notwithstanding this, I argue the state - and our analysis of it - is now obscuring impkniortant questions relating to the broader political-economy, planning and governance of cities and regions. This is important because in the post-financial crisis era of austerity politics and neoliberal restructuring, the spotlight for regional growth is pointing firmly on the business sector. Speaking in the immediate aftermath of the crisis, soon to be UK Prime Minister, David Cameron argued as much: 
"Let's be clear where growth will come from. Not big government, with its Regional Development Agencies ... but entrepreneurs. New businesses, new industries, new technologies." (Cameron, 2009)

Cameron was not alone. His view reflected the broader recovery plan being composed by political and economic leaders interested in preserving some form of neoliberal consensus. What emerged in the years immediately following the financial crisis was not only a scripted role for the private sector to fuel economic recovery, but a more prominent role in shaping city and regional futures. If you believed the rhetoric, a soon to emerge private sector led agenda for regional economic development, planning and governance was going to replace (what was perceived to be) the increasingly antiquated and bureaucratic structures of state territoriality and planning.

Despite important work examining private sector engagement in subnational economic governance (Syrett and Bertotti, 2012; Harrison, 2014; Medina, 2016; d'Albergo et al., 2018), the role of business in financing large scale city-region regeneration and infrastructure projects (Raco, 2013; Jonas et al., 2014; O’Brien et al., 2019), and the privatization of urban and regional development (Knieling et al., 2012; Ward and Swyngedouw, 2018), scholars have so-far failed to fully grasp the changing role of business within regional policy, governance and spatial planning ${ }^{i}$. In this paper I posit three reasons for this: (i) a deep-seated statecentrism to how researchers and policymakers think which is closing off, and leaving us blind, to the possibility of alternatives beyond state orchestrated regionalism; (ii) what analysis there is of business involvement in regional governance is limited by talk of business per se rather than investigating the role of actual businesses; and (iii) little or no attempt to move beyond reporting and recommending the need for more business engagement as the 
outcome of research to make businesses and business engagement the object of our research. The result, I argue, is a state-territorial trap.

Breaking free from this intellectual straitjacket requires moving beyond the conceptual and methodological lock-in of business-as-usual approaches to thinking regions geographically. To achieve this the current paper centres on a detailed case study of The Peel Group's (hereafter 'Peel') Atlantic Gateway Strategy in North West England. Launched in 2008 amid the global financial crisis, what marks Peel's Atlantic Gateway Strategy out for attention is it amounts to proto regional governance by the private sector. The value of this case study is how it helps to reveal the anatomy and politics of business involvement. It enables us to examine the motivations, tactics and strategies of businesses engaged in orchestrating regional policy, planning and governance. And most crucial of all, it provides the basis to develop conceptual and analytical frameworks capable of researching the politics of business involvement in shaping regional futures.

From here the paper develops as follows. Section 2 reveals how a new landscape of urban and regional governance is emerging which features business orchestrated regionalism prominently. To substantiate the argument that we need to 'see beyond the state', Section 3 compares business orchestrated regionalism (illustrated through the case of Peel's Atlantic Gateway) with state orchestrated regionalism (illustrated through the case of Local Enterprise Partnerships). It then examines the spatial and scalar logics of Atlantic Gateway regionalism before revealing, in-depth, the motivations and strategies used by Peel. Arguing that business orchestrated regionalism is a form of tactical regionalism, this leads to a discussion of power and the implications for both people and places of greater business involvement in orchestrating regionalism. In the final part, the research reveals the practical politics and 
pragmatism by which actors are having to consolidate state and business interests as complementary alternatives to mobilise new regional (and other spatial) imaginaries, and the wider implications for how we think regions geographically.

\section{RETHINKING THE ROLE OF BUSINESS IN URBAN AND REGIONAL DEVELOPMENT}

The role of economic actors in urban and regional governance has a long and varied history but in the neoliberal era its development can be characterised by four distinct, yet interrelated, phases.

Phase 1: Growth Machines, Growth Coalitions, Urban Regime Theory (1970-1980s)

From analysing North Atlantic urban governance - and North America especially - scholars began to recognise that decisive moves away from state-led policies in favour of market-led approaches was being reflected in the pre-eminence of growth objectives in the urban policy agenda. Not only this, the allure of generating growth was uniting otherwise pluralistic interests in cities, albeit with a growing influence of the private sector and business interests in convening urban politics and shaping the nature of urban policy. The term growth machine (or growth coalition) came to be synonymous with the coming together of actors - real estate, construction and utility companies, municipal governments, local media - who stood to profit if growth resulted in land-use intensification and its subsequent effects on local land values (Molotch, 1976). These accounts are noteworthy because they became the antecedent to four decades of scholarship embodied in what Harvey (1989) termed urban entrepreneurialism - the governance shift from processes concerned primarily with the 
provision of services to those promoting economic growth 'at all costs' through entrepreneurial modes of governance.

The critique of work on urban growth machines and urban entrepreneurialism was that, among other things, it was heavily centred on US cities. This is somewhat perplexing given that countries such as the UK were undergoing very similar transformations through the 1980s But it was not until the 1990s that accounts sought to apply and test the concept in non-US contexts, such as the UK (Harding, 1991; Ward, 1996).

Phase 2: New Regionalism (1990s)

Analogous to this focus on business involvement at the city-level, the 1990 s came to be dominated by a series of accounts pertaining to a new regionalism in economic development. Essential to the new regionalist thesis was a belief that regions were competitive territories par excellence and the explanation owed much to the regionalisation of business and governance. Bringing into sharp focus arguments that economic success required a strong institutional presence - of business associations in particular - at the regional scale, new regionalist orthodoxy was soon transmitted into political practice with business, state and civic actors hastily assembling institutional arrangements designed to mobilise business interests, political coalitions and state capacities in regionally-scaled 'growth coalitions'.

Not surprisingly, research from this period analysed in some detail business engagement at the regional level. However, it only went so far. Firstly, the focus was narrowly on the role of collective business organisations (e.g. Chambers of Commerce) and economic actors in the composition of new institutional arrangements that brought together business, state and civic 
actors (e.g. Regional Development Agencies) (Jonas, 1996). And secondly, as highlighted in the UK, scholarship on the practice of implementing new regionalist thinking focused almost exclusively on reporting the institutional history of regional business associations (Burch and Holliday, 1993), mapping the extent of business engagement in new institutional structures (Valler et al., 2004), and documenting the profile of state, business and civic actors on institutional boards (Jones, 2001). Reporting, mapping and documenting taking precedence over problematising business engagement in regional planning and governance reflected how researchers would often refer to business per se rather than businesses actual. When economic actors were given voice it was nearly always a solitary 'business voice', reflected by the seemingly obligatory single private sector quote from a local business association. Absent, for the most part, were the voices of actual businesses (for a notable exception see Wood et al., 1998).

Phase 3: Global City-Regionalism (2000s)

By the 2000s the focus of attention switched to city-regions as the development focus for actors pursuing competitiveness. Marking out global city-regionalism for specific attention was how this new era in growth-oriented regionalism was shifting the focus away from the traditional territorial growth politics of state-led regionalism towards more open, networked and less governmentalised spaces of coalition formation.

On the face of it, global city-regionalism signalled a ratcheting up of the predominant neoliberal discourse championing the superiority of entrepreneurial forms of responsive local governance vis-à-vis the withering away of top-down state orchestrated regionalism. Yet the 
reality of city-regionalism delivered a very different story. In the UK, for example, cityregionalism came to be reflected in the roll out of initiatives which purported to represent the localness of coalition formation, the placing of business interests and market mechanisms at the centre of city-region development, and operationally working across functional economic geographies. Indeed, one among many initiatives were the flagship Local Enterprise Partnerships (LEPS) established in 2010 as replacements for the new regionalist inspired Regional Development Agencies launched a decade previous. But from the outset this was an initiative flowing out from central government, business engagement was highlighted to be 'thin', and very few of the 39 LEPs established could genuinely claim to be working across functional economic areas (Harrison, 2012). As Syrett and Bertotti (2012: 2312) argue, a limited understanding of private sector engagement ensures that state led city-region initiatives such as LEPs provide a "fundamentally flawed governance model".

This reveals how conventional state centred analyses are failing to understand why businesses engage, how they engage, and what impact their involvement is having. More than this, our rush to bring the state back in has led us into what I identify in this paper as a 'stateterritorial trap'. This state-territorial trap derives from an inherent presumption that perceived solutions to the problems of state-orchestrated regionalism lay in alternative stateled solutions.i. The fundamental flaw here is not so much the governance model of LEPs - or any other subnational governance model for that matter - but the failure to break the cycle of rolling forward longstanding institutional weaknesses from one state orchestrated regionalism to the next. These weaknesses extend to institutional deficits in authority, legitimacy, capability and resource necessary to enact meaningful change and correct deeprooted market failures, while at the same time burdening institutional actors with state- 
imposed mission creep and bureaucratisation. Finally, there is an inherent bias in assuming that the spatial interests of businesses are necessarily state spaces and driven solely by the motivation to access state resources and power, when they often translate into non-state spaces of business engagement and collective action (Harrison, 2014).

Phase 4: Competitive Multi-City Regionalism (2010s)

Today, a new wave of research is revealing a new spatial logic for regionalism at the 'mega' or 'multi-city' scale (Harrison and Hoyler, 2015; Wachsmuth, 2017a). To be more accurate, this fourth phase is a combination of both renewal and breaks with prior logics of regionalism. While 'mega' or 'multi-city' regionalism has been arrived at from continuous renewal of the neoliberal mantra "bigger-is-better" when it comes to the efficiency argument associated with agglomeration economics, the logic for growth and the structuring principle for coalition formation has switched to infrastructure regionalism (Table 1). This recognises that the common labour market which incentivises cooperation at the city-region scale becomes nil and void when the scalar logic for regionalism extends beyond a single metropolitan area.

In his analysis of multi-city regionalism in the US, Wachsmuth (2017b: 51) demonstrates how supply chain expansion - as one important aspect of infrastructural regionalism - has emerged as a powerful uniting logic for place-bound elites to enter into new governance collaborations at the multi-city scale, even where those cities and regions are otherwise engaged as the fiercest of rivals in the competition to attract investment and talent. This account is noteworthy because off the back of this Wachsmuth introduces "the possibility of business regionalism on a multi-city scale" (ibid.). 
Fast emerging is a new landscape of multi-city regional governance which has the potential to feature business orchestrated regionalism prominently. Nevertheless, weaknesses remain: notably, this being reported as a North American phenomenon ${ }^{i i i}$ - a point duly acknowledged by Wachsmuth - and where mention of the role and the voice of actual businesses are noticeable by their absence. Moreover, we see further evidence for the pull of the stateterritorial trap in arguments suggesting that "competitive multi-city regionalism is ... structured by supra-local dynamics within the state system" (Wachsmuth, 2017a: 651 emphasis added). Representing a significant step forward in breaking free from the intellectual straitjacket of a deep-seated state-centrism afflicting contemporary regional thinking, it is the contention in this paper that more than shining the spotlight on business engagement in region-making, we need to equip ourselves with the concepts, vocabulary and methods to 'see like a business'. Only by doing this can we (i) examine the motivations, tactics and strategies of businesses engaged in orchestrating regionalisms, (ii) reveal the anatomy, politics and ethics of business involvement, and (iii) develop appropriate conceptual and analytical frameworks for researching business orchestrated regionalism and current forms of region (and other forms of place) making.

\section{'SEEING LIKE A BUSINESS': PEEL AND THE ATLANTIC GATEWAY STRATEGY}

New multi-city growth coalitions are already emerging in countries beyond the US. For example, two types of multi-city regionalism are currently being institutionalised in the UK. In 2014 the UK Government launched its 'Northern Powerhouse' initiative on the premise that if the cities of northern England were better connected, they would constitute a single functional economy with sufficient scale to counterbalance London and the south east. Multi- 
city regionalism in this instance is mobilised from above with the express intention of advancing a state priority - spatial rebalancing (Lee, 2017) ${ }^{\text {iv }}$ - albeit with significant influence being brought to bear by the lobbying activities of economic actors ${ }^{v}$. In contrast, multi-city regionalism is also emerging from below.

Originally launched in 2008, Peel's Atlantic Gateway is a private sector vision for multi-city regionalism centred on the Manchester and Liverpool city-regions. Premised on the principle that investment in infrastructure is key to unlocking the growth potential of these two cityregions, marking out the Atlantic Gateway for attention is how it represents a case of multicity regionalism in action. More than this, over the past ten years the Atlantic Gateway has institutionalised to become a space of governance with its own Partnership Board. But more critical than all of this, it was the initial vision of one business - Peel. What follows in this paper therefore extends analysis pointing to the possibility of "business regionalism" on a multi-city scale to explore the possibilities for "business orchestrated regionalism".

\section{Methodology}

To achieve this, the paper draws on data from interviews and desk-based research. Coordinated alongside desk-based research analysing policy and strategy documents, Hansard, published board papers from local council meetings and news media reports for the period 2008-2017, what follows draws mostly on 45 semi-structured interviews conducted across two periods of fieldwork in 2013 and 2016 with Atlantic Gateway board members (both

public and private), local authority officials, government departments, businesses and business representatives. Data were subjected to textual analysis and thematically coded. 
Quotations are used to inform and support the key findings presented, with the names of interviewees anonymised. The key methodological innovation involved going beyond the usual suspects of interview research into spatial economic governance (those state actors and business organisations operating at the local, regional and national level) and giving voice to a diverse range of business actors (most notably, the individual firm actors themselves) such that we can 'see like a business'. Interviews were conducted with actors and firms directly involved, partially engaged, or likely to be impacted by Atlantic Gateway and investigated the motives, strategies and tactics for firms engaging (or not) in business regionalism.

\section{SEEING BEYOND THE STATE, SEEING LIKE A REGION?}

State orchestrated regionalism vis-à-vis business orchestrated regionalism

In 2010, the UK Government announced a major overhaul of state orchestrated regionalism in England. Regional institutions were to be abolished by 2012 and replaced with a new generation of 39 Local Enterprise Partnerships. This latest incarnation of state orchestrated regionalism was significant in three ways. First, critics argued it was the latest in a long line of symbolic regionalisms whereby the state gives the impression of looking interested in regional economic growth, but systematically fails to deploy the resources necessary to correct deeprooted market failures and tackle sociospatial inequalities (Harrison, 2017). Second, this incarnation was far less governmentalised - effectively contradicting the growth logic of competitive regionalism by initiating a form of austerity regionalism (Etherington and Jones, 2016; Davidson and Ward, 2018). And third, state orchestrated regionalism in the guise of 
LEPs stood in stark contrast to the recently launched business orchestrated regionalism offered by Peel through their Atlantic Gateway initiative (Table 2).

Neatly illustrating this point, a National Audit Office (2016) survey of LEPs saw only $23 \%$ report having sufficient staff (average full-time equivalent staff employed by LEPs is 8 compared to Peel's 2500). Moreover, one interviewee highlighted the problem LEPs face:

"The LEP is all about getting other people to do the work for you. What is the LEP all about? It's about getting the best deal for the area, but the irony is we cannot do any of it. I have 3.5 staff here. Others have got to deliver it. I tell you, Peel have ten times the number of staff I have whose sole job it is to get the money in." (interview, LEP officer)

The same NAO survey revealed only $5 \%$ agreed the LEP has enough available resource to meet the expectations placed on them by government. This paints a picture that while the can-do bravado heralding the formation of LEPs and Atlantic Gateway were carbon copies of the same economic orthodoxy trumpeting the agglomerative urban growth potential of functional city-regional economies, the substantive reality was the state orchestrated vision offered few signs of encouragement, whereas the business orchestrated regionalism afforded by Peel's Atlantic Gateway presented a seemingly credible alternative:

"If anywhere in the UK can develop the critical mass and momentum to become an alternative growth pole to London, it is the Atlantic Gateway ... [T]here has never been a credible proposition of that nature in Britain to achieve something decades of regional policy failed to achieve" (Heseltine and Leahy, 2011: 56-57). 
This becomes more significant when we factor in other recent state-orchestrated models. The launch of a Northern Powerhouse promised much but, as Lee (2017: 487) quickly uncovered, the "lack of strategic clarity, defined plan or accountable institution, the creeping geographical remit and the relatively limited finances" led to claims that this much vaunted multi-city regionalism initiative was ostensibly "a politically motivated branding exercise". More significant has been the new deal-making approach to devolution with cities and regions vying to sign what appear to be lucrative deals with UK Government to secure long-term investment and powers ( $\mathrm{O}^{\prime} B$ rien and Pike, 2019). The problem is the inherent contradiction in all state-orchestrated forms of regionalism in the UK over the past decade - the 'devolution of austerity' - because as Etherington and Jones (2018) illustrate, you have to consider the broader political economy of cuts to local government funding ( $f 1.1$ billion over 4 years in Sheffield vis-à-vis the (offered) f0.9 billion devolution deal over 30 years).

'Making up a region': unpacking the spatial and scalar logics for business orchestrated regionalism

With collective investments owned ( $£ 2.3$ billion) and under management worth more than $£ 5$ billion, Peel's total direct and indirect investments extend to 3.7 million $\mathrm{m}^{2}$ of built estate, 28,000 hectares of land and water, and 4.6 million $\mathrm{m}^{2}$ of future development. Most of this investment is centred on North West England, and more specifically a 35-mile urban corridor connecting Liverpool in the west to Manchester in the east. This is the focus for Peel's Atlantic Gateway Strategy, which is pertinent for two reasons. First, Liverpool and Manchester have a fierce rivalry which models of entrepreneurial urban governance and zero-sum urban competition stoked further during the 1980s and 1990s. Meanwhile, second, Peel have had a 
very fractious relationship with Manchester City Council who see major investments into Peel's development sites between Liverpool and Manchester (notably in the 1990s the Trafford Centre retail development, and in the 2000s MediaCityUK) as shifting the centre of gravity for investment, and ultimately revenue and growth, away from the urban core of the Manchester city-region.

As will be seen below, what has happened for Liverpool, Manchester and Peel to put this rivalry to one side and support certain priorities under Atlantic Gateway substantiates Wachsmuth's (2017b) analysis that infrastructure and supply chain expansion are structuring principles for the rise of multi-city growth coalitions. But to understand the Atlantic Gateway story requires much more than just an understanding of the scalar logics of regionalism; it necessitates engagement with recent geographical thinking around the idea of 'making up' regions (Cochrane, 2013; Harrison et al., 2017).

From 1973 onwards there have been various attempts to establish the Liverpool-Manchester corridor as a space for planning and governance in public sector thinking (Hincks et al., 2017). The 'making up' of Atlantic Gateway began in 2008 when Peel launched Ocean Gateway to capitalise on their strategic assets in the Liverpool-Manchester urban corridor:

"Make no bones about it, the reason that Peel came up with Ocean Gateway was because it's got a huge amount of development land. It believes that this represents a huge opportunity and asset for the North West of England. But actually, ultimately, Peel wants to see that land developed to make profits for Peel. There's nothing wrong with that but that's why others said, 'look at the bigger picture'." (interview, Greater Manchester Combined Authority policy advisor) 
The first thing to recognise is how the fundamental principle of growth coalition formation land-use intensification - remains intact, but there is now a 'bigger picture' reflecting how Ocean Gateway was ostensibly a hastily constructed regional imaginary. Created at the whim of one private sector developer and landowner its geography was very loosely defined by the location of 50 sites owned or manged by Peel.

A matter of months later Ocean Gateway morphed into Atlantic Gateway. This came at the insistence of the Northwest Regional Development Agency who, in return for their statutory support as the responsible body for setting the long-term regional economic and spatial strategy, compelled Peel to include other stakeholders - both public and private - with strategic assets and interest in the Liverpool-Manchester urban corridor. With this came important changes to the scalar logic for regionalism and a remaking of this newly imagined region.

While the geography of Ocean Gateway was kept deliberately vague, the structuring principle was anything but. Recognising that the widening of the Panama Canal (2007-15) would double capacity, as well as allowing larger vessels able to carry twice the cargo, Peel saw an opportunity to capitalise on changing trade patterns, provided the port, transport and logistics infrastructure they owned locally in the Liverpool-Manchester corridor could be upgraded. The principle of supply chain expansionwas evident in the initial spatial framing of Ocean Gateway - as a regional transportation network connecting into the European Commission Trans-European Transport Network (TEN-T) - and confirmed in the interviews:

"You've got to understand that $50 \%$ of goods that come into the south of England by port end up north of Birmingham. It's crazy. We have to be looking at the total supply chain, from where goods are manufactured to where the customers receive them. 
Atlantic Gateway is Peel saying there is a huge international opportunity here. Changes in the logistics industry and the change in world shipping patterns through the expansion of the Panama Canal give us a chance to change it. Is it working? Too early to say but we now have more shipping companies headquartered, or have their UK or European headquarters, in Liverpool than before and more are beginning to use the Port of Liverpool whereas previously they didn't. We know that some of the major manufacturers, including Jaguar Land Rover, are now using the Port of Liverpool to improve efficiency in their supply chains." (interview, port sector executive)

Yet, the requirement to engage other stakeholders catapulted Peel into negotiating the(ir) need for multi-city regionalism with actors whose principal activities were rooted in cityregionalism and out-competing their neighbouring areas for mobile capital investment.

The result was a hastily reconstructed vision and strategy simultaneously separating out and combining the competitiveness of city-regionalism with the cooperation of multi-city regionalism. Visually, the single framing of Ocean Gateway as a multi-city regional transport infrastructure network was superseded by an Atlantic Gateway geography comprising three spatial components: the Liverpool and Manchester city-regions as separate spatial entities, overlain by the original Ocean Gateway concept of a connecting urban corridor. Strategically, the political calculus for Peel to secure support for their multi-city regional strategy required them to concede that Atlantic Gateway had, first and foremost, to "support and accelerate Manchester and Liverpool city regions' growth strategies" (Peel, 2010a, p. 4). The result was governance collaboration for place-based elites across city-regional and multi-city regional geographies became clearly differentiated: 
“There's always been tension between Manchester and the Atlantic Gateway and that has always been around two things. One is around employment land and some difference in opinion between Liverpool and Manchester about key sites which sit between them. Then it became an issue around housing and a view that Atlantic Gateway could, if you weren't careful, lead to a huge amount of housing development outside of the core conurbations. Therefore, the decision was taken at a pretty early stage under Atlantic Gateway, as opposed to Ocean Gateway, that housing was out of the equation." (interview, Greater Manchester Combined Authority policy advisor)

Of course, this stands to reason because employment land and housing are both integral to the traditional growth politics of land-use intensification rather than infrastructure enabled supply-chain expansion of multi-city regionalism (Table 1). More revealing is that what started out as a more holistic growth proposition has narrowed in scope to aspects of growth where collaboration between otherwise competing city-regions can be secured. As this interviewee explains:

"We were very comfortable with supporting the Port of Liverpool, Liverpool Airport, Manchester Airport, Port Salford, Daresbury [science and innovation campus], because we see all of those as projects which, whilst they're located in one area, have benefits that go beyond Greater Manchester, or they go beyond Liverpool City Region, or they go beyond Cheshire and Warrington. What we weren't prepared to support, and this caused a bit of controversy, was when the proposition was put to us that we should support Liverpool Waters and Wirral Waters ${ }^{\text {vi }}$. Greater Manchester didn't say no, it said not unless you demonstrate what the value of those projects is outside the Liverpool City Region. Certainly, we don't think that housing projects are Atlantic 
Gateway projects. So, we've been quite firm on that and I suppose that has actually limited Atlantic Gateway's scope because if you look at the Ocean Gateway projects, quite a lot of projects were site-specific Peel projects." (interview, Salford City Council)

Here we see an example of the concessions made by Peel to embed a multi-city regional growth coalition within and alongside extant economic governance arrangements. This resulted in a less holistic growth proposition than originally envisaged (cf. Jonas, 2013) and crystallisation around the structuring principle for collaboration at the multi-city region scale. More than this though, what emerges is the spectre of multi-city regions existing as depoliticized "post-political" spaces of consensual policy-making (Allmendinger and Haughton, 2012; Etherington and Jones, 2018). Take, for example, the view of one Atlantic Gateway Board Member highlighting how multi-city regionalism, as a new "regime" of growth politics, can undermine democracy as - by design - its governance bypasses directly elected and representative democracy:

"The value added of Atlantic Gateway? Find things we can agree on, have a single voice, and then drive them hard though lobbying and presenting co-investment opportunities that are impossible to walk away from. The things we can agree on? They are those things of national and international significance that are broader than city-region or LEP geographies, things which cannot be thrown up in the air every time there is a General Election. Our democracy is blocking major investment. It is about taking long-term investment out of the political agenda. Atlantic Gateway is about getting agreement and a single voice through political and business consensus." (interview, Atlantic Gateway Board Member) 


\section{Business orchestrated regionalism as 'tactical regionalism'}

Inevitably, the prospect of private sector actors as 'region makers' poses fundamental questions about their motivation and interests. If, as Wachsmuth (2017a/b) argues, the headline motivation for governance collaboration at the multi-city region scale is supply chain expansion via public and private investment in infrastructure ${ }^{\text {vii }}$, as a general principle this can happen anywhere. So why has multi-city regionalism emerged in some places and not in others? Why does it take the form that it does? And why, in places such as North West England, did it emerge when it did? My argument is that answering these (and other related) questions can only be done by 'seeing like a business'.

Unlike Wachsmuth's (2017a) analysis of multi-city growth coalitions in the US, the Atlantic Gateway Partnership did not emerge from extant state structures (e.g. Chief Executives or Mayors of the respective cities) or an already politically-engaged representative group of business actors (e.g. Chambers of Commerce). Instead, Atlantic Gateway emerged from a single firm - Peel - meaning firm specific motivations are just as important as any general structuring principle for multi-city regionalism.

The motivating logic for Peel was manifold. First is the relative proximity of their assets: most are located along an urban corridor stretching $50 \mathrm{~km}$ from the Port of Liverpool in the heart of the Liverpool city-region, to the centre of the Manchester city-region. Peel are more placedependent than many companies their size meaning they have most to gain from (or lose from not) extending and intensifying capital circulation through improved regional infrastructure and supply chain expansion. 
Second is their history and the scars they bear from many years of protracted disputes over plans to develop their key sites ${ }^{\text {viii }}$. With ambitious plans to transition away from delivering individual multi-million-pound regeneration schemes to coordinating larger and more complex multi-billion-pound projects, Peel's Chairman, John Whittaker, made it clear from the outset that their stated goal was to secure their "own planning regime ... so we can overcome individual local authority objections" (quoted in Barry, 2008, np). As this interviewee goes on to explain, the spectre of multi-city regions existing as depoliticized spaces of consensual post-political policy-making is central to the rationale for business orchestrated regionalism:

“Peel's intention was always quite simple. They're property developers that made their money out of land and they now own a lot of the key land assets between Liverpool and Manchester. Realising the value of their immense portfolio of land means securing tenant permissions. Now they believe that they were more likely to secure the planning permissions they wanted from a development agency or development corporation type vehicle than they were from local authorities. Even though planning powers are still in the hands of local authorities they think that having a strategic vision which UK Government buys into at a very high level will help them to secure the permissions they want. Their bottom line is they want permissions and they want them in the bag. The reason they want permissions is quite simply because a permission gives certainty and the planning system which the UK Government have now produced is a system which largely breeds uncertainty at almost every level of operation. If Peel have outline permissions for these mega projects which are all 
interconnected in a small area of the North West, they are really holding all the aces" (interview, regional planner).

Here we see how supply chain expansion and land use intensification are not separate structuring principles but two sides of the coin when it comes to growth-oriented politics, with the former enabling the latter. As well as this, what is rightly emphasised is that regionmaking is never an end goal; it is the intermediate step towards enabling and achieving other stated goals.

This leads to the third motivating logic for Peel. Susceptible to obstruction by individual local authorities, Atlantic Gateway is to some extent a reactive response to governance failure and a consequence of central government rethinking its territorial organisation which in turn creates problems for a company like Peel. In the case of Atlantic Gateway, while the nascent business-inspired region pre-dates the dismantling of the regional planning, governance and economic development apparatus after 2010 by two years, the latter became increasingly important in its development when, as a company with region-wide interests, Peel were left more exposed and increasingly susceptible to obstruction by individual (and competing) local authorities.

Finally, for all that Atlantic Gateway represents a strategic vision designed to enable value to be added to Peel assets, equally it is an essential component of a wider strategy to project Peel on to a national and international stage. Amongst the interviewees there was a shared recognition that while "nobody down in London's got the faintest idea about Peel or what's going on up here" (interview, regional planner) Atlantic Gateway provides a plausible, and potentially significant, antidote ${ }^{i x}$ : 
"There are certain projects that would be big enough and strong enough to stand alone on a national scale anyway. But what Atlantic Gateway gives is a single framework that allows the whole project, the whole scheme, to go to Central Government, to go to Europe, to go on international trade delegations, and talk about and represent Peel and the North West in a way that many of the smaller projects couldn't achieve on their own. That's the value it brings." (interview, Peel Executive).

On the face of it there is nothing firm specific about this. It would be difficult to deny any significant difference between what we see here and arguments that say Peel are creating new spaces of empowerment and engagement to advance their place-dependent interests (cf. Cox, 2010), or how the politics of regionalism has become increasingly nationally and internationally-orchestrated (Jonas and Moisio, 2018) - other than Atlantic Gateway being initiated outside of state structures. But this would be to miss two important place and firmspecific points. First, as Wachsmuth (2017b) rightly notes, place-dependent firms such as Peel have much more to gain vis-à-vis multinational corporations who already have global reach and influence. Second, while Peel are asset rich, they remain cash poor. Peel's business model of acquiring significant equity stakes in major international companies (through onward selling or buying up shares) has aided corporate expansion, yet they remain vulnerable due to their heavy reliance on attracting public and private investment to enable their business plans to come to fruition. This is leading key regional actors to be deeply suspicious of Peel's motivations:

"whenever my engagement with Peel and the people behind the various projects has been, the whole reason for them being on it is to try and get public money. They very quickly come up with ways of getting public money channelled to them, that seems to 
be why they engage with the public sector, rather than (sighs) necessarily engaging with the public sector to make sure that the right things happen." (interview, private sector representative)

All of which goes a long way in explaining Peel's motivations to engage in region-making, but they are not the only firm involved. The requirement placed on Peel by regional state actors to include other public and private actors with strategic assets and interests in the region forced Peel's hand but what of these other firms - who are they, why did they engage, and what benefit did they seek from multi-city regionalism? These questions are all the more important when it becomes clear that alongside several other firms, it is Peel's major competitors in property development (The Langtree Group) and logistics (The Stobart Group) that are both now heavily engaged with Atlantic Gateway:

"It's certainly not been a barrier. We are a competitor of Peel certainly, but our involvement in Daresbury (science and innovation campus) meant we were invited to become involved in the Atlantic Gateway initiative. Our view is simple. If that initiative is taking place and it's going to have a positive effect on the region, in being able to secure attention and funding from Government, then we need to be a part of it. There's no point being on the outskirts, you need to be involved." (interview, Langtree executive)

"Stobarts are a strong participant but historically their facility at Widnes was a direct competitor to the port. They [Stobarts] bring containers into the North West by rail, we [Peel] want to bring them in by ship. But what you create is this 'logistics cluster', for want of a better phrase, where we talk about the power of the region to deliver logistics solutions to industry and commerce. Atlantic Gateway gives us the joint 
strength and the joint force of the port, Stobarts, and then other organisations that you can attract and generate interest in a way that you couldn't do as a stand-alone entity." (interview, Peel executive)

The reason for their involvement - the promise of increased visibility and funding - should come as no surprise but there is much more to it than this. In a significant symbolic move, the position of leading the Atlantic Gateway Partnership Board was transferred to the representative of The Stobart Group. What we see in this case is that competitive multi-city regionalism emphasises the spatial (collaboration between places usually in competition) but by starting to 'see like a business' we can see the functioning of Atlantic Gateway owes as much - if not more - to competitive multi-firm regionalism (collaboration between firms usually in competition). This is significant because geographical approaches to thinking regions emphasise the spatial in general, and the state spatial in particular. What the present analysis is helping to reveal is how firm-specific motivations are just as important, and why investigating the role of actual businesses as increasingly influential region-makers reveals hitherto unreported dynamics in how regional futures are being shaped .

\section{Marriages of convenience?}

There is no denying the influence that companies (such as Peel) now exert over regions (such as North West England) and their future development. But how should increased business engagement in shaping regional futures be viewed? At best, Peel are a company who responded to the calls for the private sector to fuel economic recovery, by investing at a time when others (both public and private) were not and playing a more active role in subnational economic governance (Heseltine and Leahy, 2011). At worst, Peel are predatory capitalists 
engaged in a systematic power-grab, asserting their influence to channel more public money to them and pushing through planning permissions while the state is left vulnerable by economic crisis and its own orchestration of an institutional vacuum in the English regions (ExUrbe, 2013; Ward and Swyngedouw, 2018). In their extremis both positions are evident in the debate, but most actors do not see greater business engagement as an 'either/or' question. They are conflicted, seeing it as a 'both/and' tension to be resolved in their own minds as well as practically:

“My view is not untypical. I'm one of those who can see the advantage of having a private sector organisation with this very positive agenda but who are worried about the fact that the scales have tipped so they are hugely weighted now in favour of the power and influence of the private sector, and without countervailing political institutions. The problem I and others have is this is perhaps extremely visionary, as well as perhaps extremely self-interested." (interview, ex-RDA staff)

One thing that is for sure, like many of the other apparatus of neoliberal governance, Atlantic Gateway emerged as an unstable fix to an economic and political crisis. Nonetheless, ten years after inception its efficacy as an exemplar of business orchestrated regionalism is becoming clearer.

It goes without saying that Atlantic Gateway has brought Peel out of the regional shadows and exposed the company to increased scrutiny by politicians, journalists, and academics alike. At its core this attention revolves around a single issue - dependency. Expanding on this, the major concern is whether business orchestrated regionalism amounts to the right kind of business engagement? Or, is business orchestrated regionalism a sign that too much power has been ceded to the private sector and our regional futures are now too dependent on the 
corporate growth strategies of (predatory) capitalists? Certainly, the state-led reaction to Peel's region-making has revolved around a view that business engagement is all well and good but only if it is on their terms.

All of which brings us back to the original problemata of business orchestrated regionalism vis-à-vis state orchestrated regionalism. The crux of the matter is that no amount of boosterism or can-do bravado hides that neither business, nor the state, has absolute power to shape regional futures. Take as an example the following two quotes, the first from a critical report by independent thinktank and the second from the then Executive Director of Atlantic Gateway:

"By using its vast wealth, actual or perceived, to wield power and influence - and by focusing upon key regeneration and infrastructure projects in often deprived areas Peel is effectively (if not consciously) holding local and national government to ransom. Local authorities ... have seized upon Peel's offers of 'investment' largely because they have been the only offers on the table. As has been repeatedly acknowledged in Peel planning applications: "There is no Plan B". Peel knows this and has used its 'clout' to secure commercially advantageous deals" (ExUrbe, 2013: 212).

“We don't have power as such because we are not a bureaucratic organ [...] our power lies in investment, the way we get people working together, the power in getting things done" (Susan Williams, quoted in Morgan, 2012: 6).

The key question emerging from this is who has what power to influence whom? What the present analysis helps reveal is the way in which companies such as Peel are mobilising new forms of business orchestrated regionalism as strategies to circumvent the inherent problems 
of incessant state-territorial restructuring and the strict terms on which they can engage in subnational economic governance. The changing dynamic which business orchestrated regionalism represents is firms such as Peel becoming increasingly proactive in setting out their terms for engaging in subnational economic governance rather than reactively responding to the latest state spatial restructuring and accompanying invitation to engage on the state's terms. What this ultimately comes down to is who is now setting the agenda - who is on the front foot and who is on the backfoot? In the case of Atlantic Gateway, Peel were making all the first moves and the state was at risk of losing control of the agenda in North West England.

Somewhat in contradiction the state response has been to challenge, facilitate, and co-opt business orchestrated regionalism. The first visible manifestation of the state's response has been increased scrutiny and - perhaps unsurprisingly - criticism of Peel, and the challenge increased dependency on private sector involvement presents for the people and places impacted by their activities. This has often come in the form of public officials voicing their frustration at the dependency on private developers, all the time running counter to their own call for greater business engagement in subnational economic governance. Every facet of Peel's operation has come under increased scrutiny lately, as the following extract from the UK's Public Accounts Committee reveals in the context of how dependent the UK's public service broadcaster - the BBC - is on Peel and their site in Atlantic Gateway:

"The BBC risks becoming overly dependent on the Peel Group for long-term success at Salford. The Peel Group owns the BBC's buildings at Salford, the on-site studio facilities and surrounding property. The future development of the site, and the cost of occupying it, particularly after the BBC's lease at Salford ends, is therefore 
dependent on the Peel Group's future strategy. The BBC's relationship with significant partner organisations also involves potential reputational risks ... for example, the extent to which partner organisations are transparent about their tax status in the UK and the amount of tax they pay." (Public Account Committee, 2013: para 4).

Drawing attention to Peel's tax affairs is noteworthy because while one part of the UK Government has been highly critical of Peel for their tax contribution, another part of government machinery has been busy granting Peel's two major development sites Liverpool Waters and Wirral Waters - Enterprise Zone status, which brings with it tax relief and simplified planning rules. ${ }^{x}$. Peel can now offer tax incentives (up to $100 \%$ business rate discount worth up to $£ 275,000$ per business over a 5 -year period) to tenants in the first years of occupancy, increasing the likelihood of occupancy and Peel's ability to generate returns on their investment, while delivering the promised 44,000 jobs created and any business rates growth generated by the Enterprise Zone being available for reinvestment in local economic growth ${ }^{x i}$. On the face of it, this reveals that state's response of simultaneously challenging and facilitating to be incoherent. In part, this is not surprising. After all the state is on the back foot, reacting to Peel's first moves, and the rise of business orchestrated regionalism is a new phenomenon meaning there is no manual on what an appropriate response constitutes. In this way we can look to other notable examples, such as the Amazon HQ2 location decision in the United States, to see the considerable power of some businesses in creating favourable investment conditions, and the subsequent concerns and unease among local politicians and residents about the nature of those concessions (which in the case of Amazon eventually led them to pull back three months after their initial decision to locate in New York). There are similar parallels with other large-scale business-oriented transport and infrastructure led 
developments (e.g. airports, high speed rail) where the scale of investment means normal local jurisdictional rules and regulations simply do not apply and are bypassed in favour of expeditious permitting and approvals to appeal to global investment firms (Addie, 2014). But part also has to do with the contemporary neoliberal mantra of actors collaborating and competing in almost equal measures.

However, for all that this political toing and froing has been capturing the headlines, closer examination of the politics at play reveals an even more significant third response by the state that illustrates the broader dynamics of state and business orchestrated regionalisms. This centres on the state's attempts to co-opt Atlantic Gateway and, in so doing, jump ahead of Peel in setting the agenda and effectively orchestrate business orchestrated regionalism. Take, for example, this statement from the then Chancellor of the Exchequer, George Osborne (2014, emphasis added):

“I've set out my plan to create a Northern Powerhouse. Today we start to deliver it. Today we are investing in science. We're building the Atlantic Gateway. And today I'm setting out how we're going to connect up the great northern cities."

Here we see a complete contrast with David Cameron's sentiments (quoted in the introduction) around what business can do for the state post-financial crisis. What we see now is the state reasserting itself and claiming the agenda by co-opting Peel's bottom-up business orchestrated multi-city region initiative - Atlantic Gateway - into their top-down state orchestrated multi-city region initiative - Northern Powerhouse.

Against this backdrop, Peel have sought to capitalise on the new political support for investment in Northern England by manoeuvring themselves into position as the animateur 
of investment and development in both forms of multi-city regionalism. Still commited to Atlantic Gateway, Peel demonstrated fleetness of foot to reimagine their 'region' of interest as the much larger, scaled-up version of multi-city regionalism championed by the state, expanding Peel's governance horizons far beyond the original Ocean Gateway imaginary (50 Peel sites along a 35-mile urban corridor in one region) to present a new vision comprising 150 Peel projects across the whole North of England (Peel, 2015). Moreover, the accompanying tone of Peel's engagement is conciliatory. Talk of 'shared agency' and 'joint benefits' (Peel, 2015: 10) reflects how, despite all the political grandstanding that surrounds private sector engagement, there is a growing realisation by those involved that the emergence of multi-city regionalism is accompanied by a more pragmatic regionalism:

“Leverage works both ways. If you've got something which both parties sign up to, there's an element that you're both forcing each other's hand to a certain degree. The private sector might be leveraging more speed in decision making from the public sector. But equally, the public sector needs to lever investment." (interview, Atlantic Gateway private sector board member)

"Forget all of that nonsense. We focus on the $95 \%$ of stuff that everybody can agree on, rather than try and create areas of conflict. There's buy-in from local authorities and from LEPs because the private sector is providing answers to big challenges. There's a pragmatism to everything we do. There is a pragmatism to everything they do." (interview, Atlantic Gateway public sector board member)

In practice, actors are having to be increasingly pragmatic in findings ways to consolidate state and business interests as complementary alternatives to mobilise multi-city regionalism (cf. Paasi et al., 2018). 


\section{CONCLUSIONS}

Rather than accept the mainstream view that we need to bring the state back in to regional thinking, this paper takes as its departure the argument that the state - and our analysis of it - is now preventing important insight into wider processes of urban-economic and regionalpolitical change in an age and reality of post-crisis neoliberal restructuring and austerity. The major contention of this paper is that an unintended consequence of endeavours to bring the state back in is leading us into a state-territorial trap. Blinkering researchers and practitioners alike to the possibilities of alternative regionalisms beyond the state, this paper builds on a fledgling body of work which is breaking free from this state-territorial trap to identify new lines of enquiry for future geographical research (Addie, 2017; Harrison et al., 2017; Wachsmuth, 2017b).

In this paper I argue that business orchestrated regionalism is an empirical reality. However, it is a new and highly significant spatial phenomenon we are ill-equipped, both conceptually and methodologically, to understand. Analysing over forty years of research into growthoriented regionalism, this paper has revealed important intellectual blind spots in our approaches to researching contemporary processes of region (and other forms of place) making. In short, this research reveals the need to move beyond business-as-usual approaches to thinking regions geographically.

As Margit Mayer (2008: 416) reminded us a decade ago "it is never the spatial form that acts, but rather social actors who, embedded in particular (multidimensional) spatial forms and making use of particular (multidimensional) forms, act". In this paper, Peel's Atlantic Gateway 
presents a stark demonstration of why we must always build this into our research practice. Reflecting on over forty years of work recognising the increased importance of businesses and capital interests in regional development, the starting point is to recognise that studies of regional governance are guilty of talking about business as opposed to talking to business. By 'seeing like a business' this paper reveals how the purity of business orchestrated regionalism - that which makes it intellectually and conceptually straightforward to distinguish from state orchestrated regionalism - is, in practice, a much more complex spatial phenomena which can only be understood as a form of tactical regionalism. In this way, the intellectual challenge is not what and where these spaces are emerging, but questions of agency (who the actors are), process (how they are mobilising) and interest (why they are engaging). Now clearly one should never overextend the generalisability of a single case-study, but while there is no denying that Peel's Atlantic Gateway is deployed in this paper as an exemplar of business orchestrated regionalism, it would be too easy to dismiss its wider relevance:

“I don't think it is unique. Peel aren't unique, it is just the scale which is unusual. There are examples in other parts of the country that are smaller scale but the principle is the same. And I think once you've proved the principle, you can then apply that anywhere." (interview, regional planner)

In one of the first studies to highlight the leading role of economic actors in post-crisis placemaking, Knieling et al.'s (2012) research on Germany revealed how Siemens in Erlangen, BASF in Rhine Neckar, and Volkswagen in Wolfsburg provided examples of place-dependent exerting much greater influence over policy spheres extending beyond those directly affecting the corporate interests of that business, and at a noticeably wider city or city-region scale. A more recent example from the UK has seen property consultants, architects, and business 
consultants launch what they present as a 'Radical Regeneration Manifesto' for the OxfordCambridge Arc multi-city region, calling for a special-purpose delivery vehicle to overall the (state's) tax and planning systems in order to deliver the infrastructure needed to unlock private-sector led regional economic growth (Bidwells et al., 2019).

Allied to this, the broader political-economy of late-capitalism is providing the conditions necessary to enable the rise of business regionalism at the multi-city scale (see Wachsmuth, 2017a/b). This means that not only are businesses becoming more influential actors in region (and other forms of place) making, they urgently need to become a more central component of our research design. In this paper, I have argued that we need to 'see like a business' and provided a new research framework for putting actual businesses at the centre of research agendas. This does not come at the expense of the state. What this research reveals is there is much to be gained, both intellectually and practically, from moving away from business-asusual approaches to regional theory and regional policy making which have routinely started with the state and then tried (and failed) to bring business in. As well as state-orchestrated regionalism, what we should be focusing our attention on are those alternative regionalisms which are increasingly coming to the fore, starting with the actors involved (e.g. businesses, universities) and then how they engage with the state. This is critical if we are to better understand the role of non-state actors in economic governance, spatial planning and placemaking, but also offer new insights into extant debates with the recognition among many of those interviewed that "public-private partnership boards are becoming more and more commercial" (interview, Atlantic Gateway private sector board member). Allied to this, the private sector is not homogeneous, economic actors do not all operate with the same motivations, and context matters. The companies which feature in this research - Peel, 
Stobarts, Langtree - are but one-third of the firms represented on the Atlantic Gateway Board, let alone operating in the case-study region itself, but evident by focusing on these firms is how firm specific motivations require a new approach to uncovering how different fractions of capital are mobilising in different ways, taking up differing roles and pursuing agendas in shaping regional futures. This has important implications and opportunities which necessitates a broader debate about the theories, methods, and concepts we possess for thinking regions geographically, and more specifically, seeing like businesses. 


\section{Acknowledgements}

The underpinning research for this paper was funded by a Regional Studies Association research grant, while the written paper has benefitted from feedback received at various international conferences, research seminars, as well as very constructive feedback from three external reviewers and the editors of the journal. 


\section{REFERENCES}

Adams, D. \& Tiesdell, S. (2010). Planners as market actors: rethinking state-market relations in land and property. Planning Theory \& Practice, 11, 187-207.

Addie, J. P. (2014). Flying high (in the competitive sky): conceptualizing the role of airports in global city-regions through "aero-regionalism". Geoforum, 55, 87-99.

Addie, J. P. (2017). From the urban university to universities in urban society. Regional Studies, 51, 1089-1099.

Allmendinger, P. \& Haughton, G. (2012). Post-political spatial planning in England: a crisis of consensus? Transactions of the Institute of British Geographers, 37, 89-103.

Bafarasat, A. \& Baker, M. (2016). Building consensus for network power? Some reflections on strategic spatial planning in the North West region of England. Environment and Planning C: Government and Policy, 34, 900-926.

Barry, C. (2008). Planning supremo seeks planning revolution. Manchester Evening News Business, 8 September.

Bidwells, Perkins + Will \& Blackstock Consulting (2019). Radical Regeneration Manifesto. Available @ www.radicalregen.co.uk

Burch, M. \& Holliday, I. (1993). Institutional emergence: the case of the North West region of England. Regional Politics and Policy, 3, 29-50.

Cameron, D. (2009) Leader's Address - Conservative Party Conference, 8 October, Manchester.

Cox, K. (2010) The problem of metropolitan governance and the politics of scale. Regional Studies, 44, 215-227. 
Crosby, N. \& Henneberry, J. (2016). Financialisation, the valuation of investment property and the urban built environment in the UK. Urban Studies, 53, 1424-1441.

d'Albergo, E., Lefèvre, C. \& Ye, L. (2018). For a political economy of metropolitan scale: the role of public-private relations. Territory, Politics, Governance, 6, 182-198.

Davidson, M. \& Ward, K. (eds) (2018). Cities under Austerity: Restructuring the US Metropolis. SUNY Press: Albany, NY.

Etherington, D. \& Jones, M. (2016). The city-region chimera: the political economy of metagovernance failure in Britain. Cambridge Journal of Regions, Economy and Society, 9, 371-389.

Etherington, D. \& Jones, M. (2018). Re-stating the post-political: Depoliticization, social inequalities, and city-region growth. Environment and Planning A, 50, 51-72.

ExUrbe (2013). Peel and the Liverpool City Region: Predatory Capitalism or Providential Corporatism? ExUrbe, Liverpool. Available: http://media.wix.com/ugd//440822_22c65849313bcedd42dc15d57426cd04.pdf (last accessed 21 June 2018).

Harding, A. (1991). The rise of urban growth coalitions, UK-style? Environment and Planning C: Government and Policy, 9, 295-317.

Harrison, J. (2012). Life after regions? The evolution of city-regionalism in England. Regional Studies, 46, 1243-1259

Harrison, J. (2014). Rethinking city-regionalism as the production of new non-state spatial strategies: the case of Peel Holdings Atlantic Gateway Strategy. Urban Studies, 51, 2315-2335. 
Harrison, J. (2017). Constructing alternative paths to city-region policy and governance. In, Deas, I. \& Hincks, S. (eds.) Alternative Paths to Territorial Policy and Governance. Routledge: London, pp. 53-70.

Harrison, J. \& Hoyler, M. (eds.) (2015). Megaregions: Globalization's New Urban Form? Edward Elgar: Cheltenham.

Harrison, J., Smith, D.P. \& Kinton, C. (2017). Relational regions 'in the making': institutionalizing new regional geographies of higher education. Regional Studies, 51, 1020-1034.

Heseltine, M. \& Leahy, T. (2011). Rebalancing Britain: Policy or Slogan? Liverpool City Region - Building on its Strengths: An Independent Report. London: Department for Business, Innovation and Skills.

Hincks, S., Deas, I. \& Haughton, G. (2017). Real geographies, real economies and soft spatial imaginaries: creating a 'more than Manchester' region. International Journal of Urban and Regional Research, 41, 642-657.

Jonas, A.E.G. (1996). In search of order: traditional business reformism and the crisis of neoliberalism in Massachusetts. Transactions of the Institute of British Geographers, $21,617-634$.

Jonas, A.E.G. (2013). City-regionalism as a contingent 'geopolitics of capitalism'. Geopolitics, $18,284-298$.

Jonas, A.E.G, Goetz, A. \& Bhattacharjee, S. (2014). City-regionalism as a politics of collective provision: regional transport infrastructure in Denver, USA. Urban Studies, 51, 24442465.

Jonas, A.E.G. \& Moisio, S. (2018). City regionalism as geopolitical processes: a new framework for analysis. Progress in Human Geography, 42, 350-370. 
Jones, M. (2001). The rise of the regional state in economic governance: 'partnerships for prosperity' or new scales of state power? Environment and Planning A, 33, 1185-1211. Knieling, J., Othengrafen, F. \& Preising, T. (2012). Privatization of urban and regional development: Achieving social benefits or business objectives? 'Corporate spatial responsibility' or 'corporate spatial strategy'? Raumforschung und Raumordnung, 70, 451-464.

Lee, N. (2017). Powerhouse of cards? Understanding the 'Northern Powerhouse'. Regional Studies, 51, 478-489.

Mayer, M. (2008). To what end do we theorize sociospatial relations?' Environment and Planning D: Society and Space, 26, 414-419.

Medina, I. (2016). Are business associations involved in regional politics? Evidence from Spain and the United Kingdom. European Urban and Regional Studies, 23, 389-405.

Molotch, H. (1976). The city as a growth machine: toward a political economy of place. American Journal of Sociology, 82, 309-332.

Morgan, P. (2012). People are now thinking much more creatively about how we can get things done - Together. The Times - Business Insight, 29 November, p. 6.

National Audit Office (2016). Local Enterprise Partnerships Census. NAO: London.

Neffke, F., Hartog, M., Boschma, R. \& Henning, M. (2018). Agents of structural change: the role of firms and entrepreneurs in regional diversification. Economic Geography, 94, 23-48.

O’Brien, P., O'Neill, P. \& Pike, A. (2019). Funding, financing and governing urban infrastructures. Urban Studies, 56, 1291-1303.

O’Brien, P. \& Pike, A. (2018). 'Deal or no deal?' Governing urban infrastructure funding and financing in the UK City Deals. Urban Studies, 56, 1448-1476 
Osborne, G. (2014). 'How we'll build the northern powerhouse'. Speech at the International Festival for Business in Liverpool, 3 July, Available @ https://www.gov.uk/government/speeches/how-well-build-the-northernpowerhouse [last accessed 13 January 2020]

Paasi, A., Harrison, J. \& Jones, M. (2018). 'New consolidated regional geographies', in Paasi, A., Harrison, J. \& Jones, M. (eds.) Handbook on the Geographies of Regions and Territories, Edward Elgar: Cheltenham, pp. 1-20.

Public Accounts Committee (2013). The BBC's move to Salford. Available @ https://publications.parliament.uk/pa/cm201314/cmselect/cmpubacc/293/29304.ht m [last accessed 21 June 2018]

Raco, M. (2013). State-led Privatisation and the Demise of the Democratic State. Ashgate: London.

Syrett, S. \& Bertotti, M. (2012). Reconsidering private sector engagement in subnational economic governance. Environment and Planning A, 44, 2310-2326.

Valler, D., Wood, A., Atkinson, I., Betteley, D., Phelps, N., Raco, M. \& Shirlow, P. (2004). Business representation and the UK regions: mapping institutional change. Progress in Planning, 61, 75-135.

Wachsmuth, D. (2017a). Competitive multi-city regionalism: growth politics beyond the growth machine. Regional Studies, 51, 643-653.

Wachsmuth, D. (2017b). Infrastructure alliances: supply-chain expansion and multi-city growth coalitions. Economic Geography, 93, 44-65.

Ward, C. \& Swyngedouw, E. (2018). Neoliberalisation from the ground up: insurgent capital, regional struggle and the assetisation of land. Antipode, 50, 1077-1097. 
Ward, K. (1996). Rereading urban regime theory: a sympathetic critique. Geoforum, 27, 427438.

Wood, A., Valler, D. \& North, P. (1998). Local business representation and the private sector role in local economic policy in Britain. Local Economy, 13, 10-27. 
'The focus of this paper is explicitly on urban and regional governance where the 'state-territorial trap' is more evident than in other areas that fit within the broader scope of urban and regional studies. For example, authors working on the built environment of cities and regions (e.g. Adams \& Tiesdell, 2010; Crosby \& Henneberry, 2016) and urban-regional economics (Neffke et al., 2018) are further ahead in recognising weak conceptions of the 'private sector' and developing categories to avail deeper understandings of the different 'types' of private sector (actors).

ii Indicative of this state-territorial trap is how Syrett and Bertotti's (2012) solution to the catalogue of problems they identify with engaging the private sector is another state orchestrated model comprising stripped-down local government with private sector contractors as strategic partners.

iii It should be noted here that although there is a much stronger tradition of literature on business regionalism and growth coalitions in the US this work is often naive about the importance of state territoriality in comparison. iv Since the Northern Powerhouse was launched, similar multi-city region strategies have been established in the Midlands (Midlands Engine) and south west England (Severn Powerhouse).

${ }^{\vee}$ This can range from lobbying of Ministers and vocal support in various media (either directly or through representative business groupings) through to less visible but no less significant attempts at influencing government policy e.g. staff secondments, funding political and economic thinktanks.

vi Liverpool Waters and Wirral Waters are $£ 5.5 \mathrm{bn}$ and $£ 4.5 \mathrm{bn}$ plans to redevelop the waterfront on either side of the Mersey estuary with new commercial and residential floor space. The plans are for a combined 38,000 apartments as well as hotels, leisure facilities and retail units.

vii Lee's (2017) analysis also reveals that $£ 6.69$ billion (86\%) of the $£ 7.8$ billion total investment committed to the Northern Powerhouse is for transport infrastructure.

viii From 1986-1996 Peel's plans for the Trafford Centre out-of-town shopping mall were subject to one of most expensive and protracted disputes in UK planning history. More recently, Peel has faced objections to their proposed $£ 4.5 \mathrm{bn}$ Liverpool Waters scheme with UNESCO warning that it would threaten the status of Liverpool's waterfront as a World Heritage Site. Despite this, when the proposal was referred to the UK Government they decided against holding a public inquiry. 
ix Interviewees were quick to stress the vacuum that Peel and Atlantic Gateway are filling in this regard in the post-RDA era.

${ }^{x}$ In this way UK Enterprise Zones are similar to Special Economic Zones which are found in many other countries.

xi Simplified planning rules include Local Development Orders that grant automatic planning permission for certain developments (e.g. new industrial buildings, changing how existing buildings are used). This makes it both quicker and cheaper for companies such as Peel. 
Table 1: Regional logics in neoliberal globalization

\begin{tabular}{|c|c|c|c|c|c|c|}
\hline Era & $\begin{array}{c}\text { Approximate } \\
\text { dates }\end{array}$ & Dominant growth focus & Dominant conceptual approach & $\begin{array}{c}\text { Territorial } \\
\text { structure }\end{array}$ & Scalar logic & Facilitating process \\
\hline Localism & 1970-1980s & Land-use intensification & $\begin{array}{l}\text { Territorial: growth machine, urban } \\
\text { regime theory }\end{array}$ & $\begin{array}{l}\text { Territorially } \\
\text { embedded }\end{array}$ & Local & Urban entrepreneurialism \\
\hline New regionalism & $1990 \mathrm{~s}$ & Economic development & $\begin{array}{l}\text { Scalar: multi-level governance, state } \\
\text { spatial selectivity }\end{array}$ & & & $\begin{array}{l}\text { Centrally orchestrated } \\
\text { regionalism }\end{array}$ \\
\hline Global city-regionalism & $2000 \mathrm{~s}$ & $\begin{array}{l}\text { Labour market } \\
\text { expansion }\end{array}$ & $\begin{array}{l}\text { Networks: relationality, nodal city } \\
\text { centrism }\end{array}$ & & & $\begin{array}{l}\text { Internationally orchestrated } \\
\text { city-regionalism }\end{array}$ \\
\hline Multi-city regionalism & $2010 \mathrm{~s}$ & Infrastructure & $\begin{array}{l}\text { Urbanisation: regional urbanisation, } \\
\text { supply chain regionalism }\end{array}$ & $\begin{array}{l}\text { Territorially } \\
\text { detaching }\end{array}$ & Global & $\begin{array}{l}\text { Business orchestrated } \\
\text { regionalism }\end{array}$ \\
\hline
\end{tabular}


Table 2: State orchestrated regionalism vis-à-vis business orchestrated regionalism in England

\begin{tabular}{|c|c|c|c|c|}
\hline & & tate orchestrated regionalism & & iness orchestrated regionalism \\
\hline & & LEPs & & Peel's Atlantic Gateway \\
\hline Functional economic area & & $\begin{array}{l}\text { Territorially-embedded; often } \\
\text { county structures }\end{array}$ & $\checkmark$ & $\begin{array}{l}\text { Liverpool and Manchester city- } \\
\text { regions }\end{array}$ \\
\hline Business-led & & $\begin{array}{l}\text { State-orchestrated public-private } \\
\text { partnership }\end{array}$ & $\sqrt{ }$ & Business-orchestrated by Peel \\
\hline Well-resourced & & $\begin{array}{l}\text { An initial share of } f 1.4 b n \text { Local } \\
\text { Growth Fund }\end{array}$ & $\sqrt{ }$ & Promise of $£ 50 \mathrm{bn}$ investment \\
\hline Well-staffed & & $\begin{array}{c}\text { Average of } 8 \text { full-time equivalent } \\
\text { staff }\end{array}$ & $\checkmark$ & 2500 staff \\
\hline $\begin{array}{l}\text { Long-term investment } \\
\text { plan }\end{array}$ & & 5 -years $(2020 / 21)$ & $\checkmark$ & $40+$ years $(2050)$ \\
\hline Large-scale ambition & & Million-pound projects & $\checkmark$ & Billion-pound projects \\
\hline Track-record of delivery & & None & $\checkmark$ & MediaCityUK; Trafford Centre \\
\hline Multi-city regionalism & & $\begin{array}{c}\text { Only } 1 / 38 \text { explicitly identifies as } \\
\text { multi-city regional }\end{array}$ & $\checkmark$ & Liverpool-Manchester \\
\hline Supply chain expansion & & Predominant focus is local growth & $\checkmark$ & $\begin{array}{l}\text { Predominant focus is transport, } \\
\text { infrastructure and logistics }\end{array}$ \\
\hline $\begin{array}{l}\text { Fragmenting urban } \\
\text { governance/politics }\end{array}$ & $\sqrt{ }$ & $\begin{array}{c}\text { England: } 8 \text { regions (1999-2010) } \rightarrow \\
38 \text { LEPs (2010-present) }\end{array}$ & 3 & $\begin{array}{l}\text { Geography extends across } 3 \text { LEP } \\
\text { areas with clear links beyond }\end{array}$ \\
\hline
\end{tabular}

